\section{Store Price Image - the Power of Perception}

\author{
Ilona Bondos \\ Faculty of Economics \\ Maria Curie-Sktodorwsk University in Lublin, Poland \\ ilona.bondos@poczta.umcs.lublin.pl
}

\begin{abstract}
The purpose of the article is to indicate the complexity of the store price image - its variously identified dimensions and dynamic character. This topic is extremely important for the effectiveness of brand store management and brand store competitiveness. The fact that the store price image is based on perception rather than reality does not facilitate the process of creating desirable store price image. In the article the results of a literature review are presented, and the final part of the paper contains some practical conclusions. Focusing on this topic is due to the significant changes in the store formats in Polish retailing.

Purpose - The purpose of the article is to indicate the complexity of the store price image - its variously identified dimensions and dynamic character. This topic is extremely important for the effectiveness of brand store management.

Design/Methodology/Approach - Literature review.

Findings - The fact that the store price image is based on perception rather than reality, does not facilitate the process of creating desirable price store image - on the contrary. Proper and effective management of store price image requires a thorough knowledge of price management. So many different aspects are behind this area of marketing activities that managers become necessary to enter into related areas - e.g. consumer behavior psychology. Since the process of shaping the price image by consumers is a dynamic process, the management of price image cannot be perceived as static.

Originality/Value - The main value of the article involves indication of complexity of the image price and thus difficulty of managing it. An overview of various approaches to the understanding of the price image, which is presented in the article, can facilitate an extremely demanding process of store price image management. Due to the current changes on the Polish retail market, it seems necessary to update the existing scientific achievements in the field of image price.
\end{abstract}

Keywords - store price image, price perception, reference price.

\section{Introduction}

It seems that from the very beginning of the conscious marketing activity retailers were convinced that this what consumers see is not always consistent with what the offer actually is. Brown (1969) has already stated that the possibility that perceptions formed may differ from the true state of the marketplace raises perplexing and important issues on buyer behavior and merchandising activities. Nowadays Trout (2008, p. 90) claims that marketing is not a battle of products, it's a battle of perceptions. Murthi

\author{
Store Price \\ Image - \\ the Power \\ of Perception
}


IJSR 5 and Rao (2012) look at pricing as an important topic for retailers since shoppers visit stores based on their subjective beliefs and feelings about a retailer's pricing activities that is price image.

\section{Definitional disarray - price image and related concepts}

Researchers have emphasized the importance of studying overall store price image (OSPI) due to the significant role of price image on consumers' (store) price perceptions and its impact on behavioral intentions (Chang and Wang, 2014). Previous research measured price image in a single dimension, such as product price level (Chang and Wang, 2014). A milestone in price image research was definition from 1970, when price image was defined as the "buyer's attitude towards price on the assortment level" (Zielke, 2011). Since that time, different research streams were created. Recently, research has indicated that price image should consist of several dimensions - this indicates the evolution in the way of understanding the price image issue. Researchers constantly write about a kind of unfortunate inattention to overall store price image in the large body of literature on pricing (Desai and Talukdar, 2003; Alba et al., 1994). These researchers define OSPI as a belief that consumers hold about the overall (or general) price image of a store, based on their perceptions of individual product prices at that store. Chang and Wang (2014) note that consumers' perceptions of OSPI do not rely only on product price image. Thus, it becomes clear that a narrow concept of product price image is a wider concept of overall store price image. In their paper, Hamilton and Chernev (2013) define price image as a general belief about the overall level of prices that consumers associate with a particular retailer. Researchers rightly note that price image is related to other constructs that pertain to consumers' evaluations of prices and retailers, price image is distinct from these concepts (Hamilton and Chernev, 2013; Diallo, 2012) (see Table 1).

Amara and Bouslama (2011) notice the specificity of a price image in highlighting the variable price in the consumers' process of perceiving a store. It relates to the global expensiveness of a store and is founded on the notion of an average price. Zielke (2011) claims that most definitions and conceptualizations of price images neglect the emotional side of this construct. In his paper (2006), he presents other point of view - price image as "a multidimensional, latent variable that consists of subjective beliefs and feeling about the pricing activities of a retailer's company, store, or category". In other of his research (Zielke, 2010), author claims that measurement of store price image is helpful in identifying discrepancies between the aspired price positioning and the customers' subjective perceptions. At the same time, he draws attention to (already mentioned) the multidimensionality of price image. As a result of such a complex measurement, it becomes possible for retailers to set priorities as to which image dimensions they should attach the most importance to. The existence of different dimensions confirms the statement from three decades: the formation of a price image is a complicated process and includes the integration of a substantial amount of price information (Büyükkurt, 1986).

Fairly interesting statement concerning the dimensions of price image is presented in the work by Amara and Bouslama (2011). However, given the general acceptance 


\begin{tabular}{lll}
\hline Constructs & Similarity & Difference \\
\hline $\begin{array}{l}\text { Price image and } \\
\text { reference price }\end{array}$ & $\begin{array}{l}\text { Both can influence how } \\
\text { consumers perceive } \\
\text { prices. }\end{array}$ & $\begin{array}{l}\text { Unlike reference prices, which are most commonly represented as } \\
\text { numerical point estimates or ranges, a retailer's price image is not } \\
\text { reducible to a specific price or range of prices and instead represents } \\
\text { a qualitative evaluation of the overall level of prices at a given retailer. } \\
\text { Price image involves a more abstract categorical evaluation than } \\
\text { the numerical precision of reference prices tied to specific offerings. }\end{array}$ \\
\hline $\begin{array}{l}\text { Price image and price } \\
\text { perception }\end{array}$ & $\begin{array}{l}\text { Both reflect consumers' } \\
\text { beliefs about are tailer's } \\
\text { prices. }\end{array}$ & $\begin{array}{l}\text { Unlike price perception, which is commonly used in reference to } \\
\text { a consumer's evaluation of a specific price, price image reflects the } \\
\text { impression of the overall price level of an entire store. } \\
\text { Price perception typically involves comparing a specific price with } \\
\text { a reference price, price image does not require specific item prices and/ } \\
\text { or reference prices as inputs. }\end{array}$ \\
\hline $\begin{array}{l}\text { Price image and } \\
\text { retailer's brand image }\end{array}$ & $\begin{array}{l}\text { Both represent an } \\
\text { overall evaluation of the } \\
\text { store that can influence } \\
\text { the evaluation of the } \\
\text { individual items offered } \\
\text { in that store. }\end{array}$ & $\begin{array}{l}\text { Unlike the store's brand image, which is a multidimensional construct } \\
\text { comprising a variety of both price and non-price aspects, price image is } \\
\text { an unidimensional construct that reflects consumer perceptions of the } \\
\text { overall level of prices at a given retailer. }\end{array}$ \\
\hline
\end{tabular}

Store Price
Image -
the Power
of Perception

Source: Hamilton and Chernev (2013).

of the multidimensional nature of this issue, mainly noteworthy is Zielke's (2010) approach. In his paper, five image dimensions were selected, whose relevance and the relationships between them differ in terms of store formats. These dimensions are defined as follows:

- Price-level perception - the perception of prices without taking quality differences into account. On a category, store or retailer level, price-level perception is synonymous with price-level image. For single products, price-level perception is synonymous with the reference price.

- Value for money - the trade-off between give and get components. In a retail context, value for money is the outcome of a trade-off between sacrifices and utilities derived from product and store attributes.

- Price perceptibility - the ease with which a customer can find or see products' prices in the store.

- Price processibility - the ease of price processing, especially when comparing the prices of alternative products at the point of sale.

- Evaluation certainty - the ease of perceiving by customers the price-evaluation process.

A slightly different approach to the concept of price image is presented by Chang and Wang (2014). These researchers looking into price image have identified four antecedents on overall store price image. Their approach was consistent with the work by Zielke because of the close relationship of individual factors with the price. But in this case the notion of price image was almost literally spread into 
IJSR 5 prime factors. The first component of OSPI was price value image (the consumers' perceived quality and sacrifice when comparing one store's price level to one or more other stores) which corresponds with value for money in Zielke's (2010) idea. The second component was price rewards image (the consumers' perceptions of rewarding benefits offered by a retail store, these are tangible benefits that retail store offers customers in return for loyalty). The third component was price fairness image, it is defined as the extent to which a consumer's assessment of a retail store's price and the price of other comparative retail stores is reasonable, acceptable, or justifiable (Xia et al., 2004). Whereas Diller (2008) claims that both theoretical and empirical findings show that the subjectively perceived fairness also represents a multi-dimensional construct. Such observation makes the concept of price image even more complex. The last component of OSPI was price pleasure image - consumers' affect (e.g. happy or angry) toward prices at a retail store. This element is a proof of acceptance of the definition proposed by Zielke (2006).

In other research approach, next to non-price factors, some price-related factors as retailer-based price image factors are identified. Interestingly, in their essence these factors differ from those presented above. According to Hamilton and Chernev (2013), in addition to the overall price level, dispersion of prices (the degree to which a retailer's prices are competitive across different product categories can) also influence price image. These researchers identify, as others price-related factors, price dynamics, pricerelated polices and price-related communications.

The last issue is especially important because of its close link with retailer's reputation - price-based advertisements are much more effective, if the sender is perceived as fair (Anderson and Simester, 2009). These authors (2003) also claim that in order to get effectiveness of pricing cues, these price-based communication should be implemented systematically. Whereas Raghubir (2006) in his work alludes to prospect theory. This great achievement of Kahneman and Tversky (1979) is also applicable in the context of the store price image because of notion that customers evaluate money and prices not as absolutes but relative to reference points, they compare the item's actual price (AP) with their reference price (RP). Depending on the effect of these price comparisons (perceived gain or loss) price judgments are formed in customers mind. As indicated by Falk et al. (2016), positive comparisons associate with low OSPI perceptions, while negative comparisons associate with high OSPI perceptions.

After presenting the depth of price image concept it is worth emphasizing once again the key words, which is the customer perception. The results of Schindler's (2001) study show that the low-price image communicated by the use of 99 endings does not reflect price-level realities in the marketplace. In Polish retail trade, the 99 endings are also widespread - the prevalence of such a price format generates risk of decline product attractiveness in the case of resign from uneven price endings (Bondos, 2016). Thus, once again - this is not about reality, it is all about perception. Zielke (2011) gives some reasons for the gap between objective prices and subjective customer perceptions: limited price knowledge, subjective price encoding, the integration of single product prices in an overall store price perception and the impact of different cues like advertising, store size, store design, and service level. For the research approach responsive to the current market situation, there should be considered a work by Falk et al. (2016). According to 
these researchers, customers seem to use payment method transparency as a price cue for establishing their perception of a store's overall price image. Having regard to the fact that payment method and price levels do not have to correlate, researchers called this finding as a payment transparency bias.

\section{Multiplicity of store price image drivers}

In the light of current literature, store price image development is a dynamic process (Lourenço et al., 2015). Such a view on price image changes the approach to process of price image management. Consumers' store price beliefs are gradually updated during store visits (Magi and Julander, 2005). As Hamilton and Chernev (2013) note, prior research has shown that the frequency with which consumers encounter low prices when evaluating a retailer's assortment is more influential in determining price image than the depth of its price advantages. And what is important, this observation is true even in contexts in which consumers already have strong prior beliefs about this retailer's price image (Alba et al. 1994). Vanhuele and Dreze (2002) rightly point out that consumers have a strong interest in keeping a knowledgebase of prices for products they frequently purchase because this knowledge base enables them to assess the attractiveness of advertised promotions, alerts them to price increases, and enables them to compare prices across stores. But even consumers who have quite good knowledge about the store's expensiveness are likely to process new incoming price information to keep price beliefs up to date.

Researchers distinguish three types of price information processing that lead to learning new price knowledge. The first one is intentional (active price search), the second is incidental (price noticed by chance at product choice), and the last one is unconscious (minimal attention to and encoding of price stimuli making price memory implicit) (Jensen and Grunert, 2014). In this context, price transparency is not without meaning. It is the degree to which market participants know the prevailing prices and characteristics or attributes of goods or services on offer (Soh et al., 2006). Zhang and Jiang (2014) note that the vast literature has suggested that consumers should benefit from increased price transparency. Informed consumers can then buy at the best price, which, in turn, intensifies price competition and hurts sellers. But in their paper, researchers show that increased transparency does not always benefit consumers and hurt the seller. Rather, it can lead to fewer purchases, a higher transaction price and a greater seller profit, despite that consumers' uncertainty is resolved and their haggling becomes more aggressive. Undoubtedly, Internet environment represents the ideal platform for enabling price transparency to increase (Rossi and Chintagunta, 2016).

As indicated by Lombart et al. (2016), the consequences of retailers' price image are seldom investigated. It seems that the most important argument for a proper understanding of the price image and concentration on its antecedents and consequences is the impact on consumer behavior. As Lourenco et al. (2015) note, consumers use store price images to guide their store choice and purchasing decisions. Researchers agree that because of power of perception, managing store price image has become a major concern in retail pricing practice. A critical question for retailers is which product categories are more salient in the consumer store price image formation process and

\author{
Store Price \\ Image - \\ the Power \\ of Perception
}


IJSR 5

why (Grewal and Levy, 2007). In their paper, Lombart et. al (2016) show that price image has a positive and significant impact on consumers' satisfaction with the retailer. What is important, is that impact is whatever consumers' price consciousness is (low versus high). Price consciousness is the degree to which consumers focus on paying low prices, so a price-conscious consumer seeks to minimize the price paid for an item, which relates to savings (Konus et al., 2008). Considering the above, managers should be aware of the relationship between the price cuts on some products in actual store offer and impact of these selective reductions on brand store image, especially the store price image (Cox and Cox, 1990). Despite the passage of time, still true is Nystrom et al.'s (1975) recommendation that store managers should not only consider the pricing of individual items, but also the need for a favorable store price image. Some researchers pointed to the special account in the analysis of the price advertising effectiveness depending on selling cost level (Shin, 2005; Simester, 1995).

In the context of the buyers price sensitivity, store formats and offered types of brands (leader brand and/or own brands) are also crucial. According to researchers, store formats are competing categories of stores types that provide specific benefits to match the needs of different customer types and shopping situations (Zielke, 2010). However, there is disagreement as to the nature of store format impact on store price image. In their research, Chang and Wang (2014) show the moderating role of retail store formats in the effects of the antecedents on OSPI. Whereas Lourenco et al. (2015), look at the store format's influence on store price image as an external factor. As for the single issue, there is a consensus - the drivers of store price image beliefs may differ between store formats (Zielke, 2010; Zielke and Toporowski, 2012; Hamilton and Chernev, 2013; Lourenco et al., 2015).

\section{Conclusions}

The intention of the author was to demonstrate the complexity of the subject store price image. Management of store price image is not as simple as some practitioners may think. Therefore, adding the word "supermarket" to the name of the retail chain will not cause a sudden change in the perception of the store price ${ }^{1}$. Proper and effective management of store price image requires a thorough knowledge of price management. So many different aspects are behind this area of marketing activities that managers become necessary to enter into related areas - e.g. consumer behavior psychology. Analyzing the national scientific achievements, it should be noted that price management seems to be a neglected issue in Polish scientific literature. The observation of market reality entitles to the conclusion that the marketing practice is anticipating the theoretical achievements connected with pricing (Bondos and Lipowski, 2015). It seems that the theory should facilitate practical action rather than follow in the footsteps of practice. Therefore, one thing is undoubtedly certain - an overall store price image is a multidimensional construct and its creation is a dynamic process. If so, it is not possible to elaborate the

1 This is a direct reference to the example of Polish retail stores chain "Piotr i Pawel" - the name of the store chain was expanded with the word "supermarket" in order to be perceived not as an expensive delicatessen (Rabij, 2016). 
final definition of price store image. And, as a result, there is no a finite attitude to the process of price image management.

\section{References}

Alba, J. W., Broniarczyk, S. M., Shimp, T. A. and Urbany, J. E. (1994). The Influence of Prior Beliefs, Frequency Cues, and Magnitude Cues on Consumers' Perceptions of Comparative Price Data, Journal of Consumer Research, Vol. 21, No. 2, pp. 219-235.

Amara, R. B. and Bouslama, M. (2011). Creation of Price Image Measurement Scale and Comparing Perceptions of Price Image Dimensions of Two Sales Formats, IBIMA Business Review, Vol. 2011, p. 15.

Anderson, E. and Simester, D. (2003). Mind Your Pricing Cues, Harvard Business Review, Vol. 81, No. 9, pp. 96-103.

Anderson, E. and Simester, D. (2009). Price Cues and Customer Price Knowledge, [in:] V. Rao (Ed.), Handbook of Pricing Research in Marketing, Northampton, Edward Elgar Publishing, pp. $150-166$.

Bondos, I. and Lipowski, M. (2015). Usage of Assumptions of Value-Based Pricing in Bundling Strategy, Zarzadzanie. Teoria i Praktyka, Vol. 12, No. 2, pp. 39-44.

Bondos, I. (2016). Cena jako marketingowy instrument oddziaływania na konsumentów (Price as a marketing instrument of influence upon consumers), Wydawnictwo UMCS, Lublin.

Brown, F. E. (1969). Price Image Versus Price Reality, Journal of Marketing Research, Vol. VI, pp. $185-191$.

Büyükkurt, B. K. (1986). Integration of Serially Sampled Price Information: Modeling and Some Findings, Journal of Consumer Research, Vol. 13, No. 3, pp. 357-373.

Cox, A. D. and Cox, D. (1990). Competing on Price: The Role of Retail Price Advertisements in Shaping Store-Price Image, Journal of Retailing, Vol. 66, No. 4, pp. 428-445.

Desai, K. K. and Talukdar., D. (2003). Relationship Between Product Groups' Price Perceptions, Shopper's Basket Size, and Grocery Store's Overall Store Price Image, Psychology \& Marketing, Vol. 20, No. 10, pp. 903-933.

Diallo, M. F. (2012). Effects of Store Image and Store Brand Price-Image on Store Brand Purchase Intention: Application to an Emerging Market, Journal of Retailing and Consumer Services, Vol. 19, No. 3, pp. 360-367.

Diller, H. (2008). Price Fairness, Journal of Product \& Brand Management, Vol. 17, No. 5, pp. 353-355.

Falk, T., Kunz, W. H., Schepers, J. J. L. and Mrozek, A. J. (2016). How Mobile Payment Influences the Overall Store Price Image, Journal of Business Research, Vol. 69, No. 7, pp. 2417-2423.

Grewal, D. and Levy, M. (2007). Retailing Research: Past, Present, and Future, Journal of Retailing, Vol. 83, No. 4, pp. 447-464.

Jensen, B. B. and Grunert, K. G. (2014). Price Knowledge During Grocery Shopping: What We Learn and What We Forget, Journal of Retailing, Vol. 90, No. 3, pp. 332-346.

Kahneman, D. and Tversky, A. (1979). Prospect Theory: An Analysis of Decision under Risk, Econometrica, Vol. 47, No. 2, pp. 263-292.

Konus, U., Verhoef, P. C. and Neslin, S. A. (2008). Multichannel Shopper Segments and Their Covariates, Journal of Retailing, Vol. 84, No. 4, pp. 398-413.

Lombart, C., Louis, D. and Labbé-Pinlon, B. (2016). Price Image Consequences, Journal of Retailing and Consumer Services, Vol. 28, No. 1, pp. 107-116.

Lourenço, C. J. S., Gijsbrechts, E. and Aap, R. (2015). The Impact of Category Prices on Store Price Image Formation: An Empirical Analysis, Journal of Marketing Research, Vol. LII, No. 2, pp. 200-216.

\author{
Store Price \\ Image - \\ the Power \\ of Perception
}


IJSR 5
Mägi, A. W. and Julander, C. R. (2005). Consumers' Store-Level Price Knowledge: Why Are Some Consumers More Knowledgeable Than Others?, Journal of Retailing, Vol. 81, No. 4, pp. 319-329.

Murthi, B. P. S. and Rao, R. C. (2012). Price Awareness and Consumers' Use of Deals in Brand Choice, Journal of Retailing, Vol. 88, No. 1, pp. 34-46.

Nyström, H., Tamsons, H. and Thams, R. (1975). An Experiment in Price Generalization and Discrimination, Journal of Marketing Research, Vol. 12, No. 2, pp. 177-181.

Rabij, M. (2016). Delikatesy, czyli biznes wysokiego ryzyka (Delicatessen e.i. high-risk business), Forbes, Vol. 12, pp. 177-180.

Raghubir, P. (2006). An Information Processing Review of the Subjective Value of Money and Prices, Journal of Business Research, Vol. 59, No. 10-11, pp. 1053-1062.

Rossi, F. and Chintagunta, P. K. (2016). Price Transparency and Retail Prices: Evidence from Fuel Price Signs in the Italian Highway System, Journal of Marketing Research, Vol. LIII, No. 3, pp. 407-423.

Schindler, R. M. (2001). Relative Price Level of 99-Ending Prices: Image vs. Reality, Marketing Letters, Vol. 12, No. 3, pp. 239-247.

Shin, J. (2005). The role of Selling Costs in Signaling Price Image, Journal of Marketing Research, Vol. 42, No. 3, pp. 302-312.

Simester, D. (1995). Signaling Price Image Using Advertised Prices, Marketing Science, Vol. 14, No. 2, pp. 166-188.

Soh, Ch., Markus, M. L. and Goh, K. H. (2006). Electronic Marketplaces and Price Transparency: Strategy, Information Technology, and Success, MIS Quarterly, Vol. 30, No. 3, pp. 705-723.

Trout, J. (2008). In Search of the Obvious: The Antidote for Today's Marketing Mess, New Jersey: Wiley \& Sons.

Vanhuele, M. and Drèze, X. (2002). Measuring the Price Knowledge Shoppers Bring to the Store, Journal of Marketing, Vol. 66, No. 4, pp. 72-85.

Xia, L., Monroe, K. B. and Cox, J. L. (2004). The Price Is Unfair! A Conceptual Framework of Price Fairness Perceptions, Journal of Marketing, Vol. 68, No. 4, pp. 1-15.

Zhang, X. and Jiang, B. (2014). Increasing Price Transparency: Implications of Consumer Price Posting for Consumers' Haggling Behavior and a Seller's Pricing Strategies, Journal of Interactive Marketing, Vol. 28, No. 1, pp. 68-85.

Zielke, S. (2006). Measurement of Retailers'Price Images with a Multiple-Item Scale, International Review of Retail, Distribution and Consumer Research, Vol. 16, No. 3, pp. 297-316.

Zielke, S. (2010). How Price Image Dimensions Influence Shopping Intentions for Different Store Formats, European Journal of Marketing, Vol. 44, No. 6, pp. 748-770.

Zielke, S. (2011). Integrating Emotions in the Analysis of Retail Price Images, Psychology \& Marketing, Vol. 28, No. 4, pp. 330-359.

Zielke, S. and Toporowski, W. (2012). Negative Price-Image Effects of Appealing Store Architecture: Do They Really Exist?, Journal of Retailing and Consumer Services, Vol. 19, No. 5, pp. 510-518. 